\title{
Perspectives of Children on Gender Roles Shown on Television
}

\author{
Aysun Dogutas \\ Educational Sciences Department, Pamukkale University, Denizli, Turkey \\ Email: adogutas@pau.edu.tr
}

How to cite this paper: Dogutas, A. (2021). Perspectives of Children on Gender Roles Shown on Television. Open Journal of Social Sciences, 9, 648-662. https://doi.org/10.4236/jss.2021.99048

Received: August 21, 2021

Accepted: September 26, 2021

Published: September 29, 2021

\begin{abstract}
A child is born in a culture and learns the culture to be able to survive in that society. This process starts at birth and ends with death which is called socialization. Family, school, friends, media, etc. are effective on socialization. Children learn gender roles by socialization. Since we are at a technology age, children mostly socialize through media. At small ages, the most important socialization object is television. They learn most of the things from the television. This study aimed to find out the effect of television on children's perceptions of gender roles. 15 secondary school students in Denizli Turkey participated in the study. Document analysis method as qualitative research was used to gather data. Participants were asked to draw a picture of a woman's role that $\mathrm{s} / \mathrm{he}$ has seen on television. Pictures were analyzed by the researcher and two other experts. Six themes emerged from the pictures of students. These are women are at contest shows, film series, alone at home, working woman, powerful woman, and violence against women.
\end{abstract}

\section{Keywords}

Children, Woman Image, Television, Socialization

\section{Introduction}

A child, born as a social creature, needs a society to be able to grow and improve. That child, gaining the first formations within the structure starting with the family, exists within an interaction that will continue throughout his/her life with other social structures. Thus, a person's development not only can be explained biologically but also can be explained related to her/his interactions with the environment. So, it can be said that a child's behaviors are not shaped alone; however, these behaviors are shaped with an attitude, thought, and behavior order which is grafted by others. Within human's daily lives there is a similarity, 
this is because of norms identified by the society and these norms are social power over people. These norms also direct emerging social codes (Eroglu, 2015). These codes which are determinants of social life are identified by social institutions such as family, school, religion, and media.

Nowadays, media is the most effective institution in identifying social codes and norms. Even though most of the children adopt the current culture and norms that they live in by the interactions with groups children are involved in such as family or school, as a reality of today's life, media interacts with kids and contributes to role stiffening by imaging some social behavior models (Gregory, 2013).

Media effects on shaping our thoughts, images, values, and perspectives. In today's world, media's effect on social reality production and consumption is inevitable. On content produced in media, there are gender roles messages to the society which are sometimes explicitly and sometimes implicitly. Also, women and men are expected to behave according to these gender roles that are given to them by the media.

There is a great relation between gender roles and socialization. Socialization is a process of learning gender roles, social rules, learning roles, and gaining roles. Gender roles are a social acceptance of an individual in which s/he accepts women and men images (Connell, 1998). Most of the time, women and men learn which behavior belongs to women and which belongs to men from films, cartoons, or advertisements (Uluyagcı \& Yılmaz, 2007).

\subsection{Gender Roles and Media}

Gender is a different concept from the concept of sex as a biological category and it is claimed that gender is sociological editing. The process starts way beyond the birth with clothes (pink for girls and blue for boys), chores, responsibilities and continues with artificial discrimination on attending social life. These discriminations become normal after a while; that is no one can realize as it was "artificial" or "normal" (K1l1c1, 2009). Gender is determined by the cultural, social, and economic factors belonged to the social structure in which the individual is in and this allows gender roles that affect people's emotions, thoughts, and behaviors. Thereby, gender roles provide organizing relations of both women and men with the whole society or with each other in all parts of lives (Saygin Sarbay, 2015).

Presentations of women on mass media have an important and effective way of reproducing gender roles and spreading them to society or changing the understanding (Mora, 2005). Binark and Gencel Bek (2010) also claimed that media can reproduce circulate sexist and unequal social relations widely and thus media can be a map showing the clues for the society. Women's image presented on mass media is like the gender roles given by society. This role can be beautiful, nice, good wife, good mother, good housewife; otherwise, it can be identified as good-bad women roles represented as violence victim or sexual object. One of 
these examples is accepted holy mother or wife, and the other is a representation of a gomer woman. Turkish televisions mostly emphasize reinforcing traditional woman identities such as self-sacrificing wives, mothers of their kids, and ladies. Besides, another important point on Turkish televisions is women's representation as sexual objects. Thus, a negative judgment is constituted by putting forward women's sexual identity in these programs (Sogut, 2019).

When the mass media's effect on individuals or society, programs of these instruments should be similar with social responsibility understanding (Mora, 2005: s. 6). Television is the most powerful one within the mass media tools. Since applying not only visuality but also emotionality, reaching a large audience, and being entertaining television is the favorite media tool within others. Thus, television has the most important role in reaching the target and reinforcing gender role messages (Giddens, 2000).

\subsection{Gender Roles and Children}

There is a common thought that every child is born with a biological gender but cannot have a social gender. It is a fact that there are differences between men and women biologically and earned at birth. However, it is inevitable of social reflections of society, in which the child is grown up, on gender information processing dependent on men and women or separating some features as acceptable or unacceptable dependent on gender (Dokmen, 2010). Biological gender cannot interfere as is social gender which has great effects on children. Since gender roles are constituted within a cultural structure, these roles give clues to the child if $s /$ he can or cannot do things within that structure. As biological gender (being women or men) is irrecoverable, social gender which is shaped with learnings is neither a causative result of gender nor a constant thing as sex (Butler, 1990).

Gender roles are coded to children starting from the early ages by the family, school, and media. O'Bryant and Corder-Bolz's (1978) studies done in 1978 remarks the effect of television on forming gender identities. According to these studies, television is effective in forming gender identities of boys and girls starting from early childhood education. According to Bem, an individual starts to form gender identity slowly by the effect of television. This gender identity, which is started to be formed, of the individual affects both perceptions of his/her own gender identity and perceptions of social environment s/he lived in (As cited in Sabuncuoglu, 2006).

A new World is established on television for children, who try to understand the social structure they lived in and to adopt the socialization process and still is in process of development. Through the instrument of television, children learn the society's cultural reflections and gender roles formed within the social structure. In the past, children learned these gender roles from the elders; however, with the development of technologies, these are presented by the mass media.

As it is seen, as a learning process during an individual's socialization gender 
roles and stereotypes are taught and reinforced to new generations. Media is the leading tool showing and adopting gender stereotypes and roles to new generations. Thus, women and man representations of programs watched by the children and its' contents are very important.

\section{Method}

This study is based on a qualitative study. Within the qualitative study, the document analysis method is used to gather data. For the data analysis, the content analysis method is used. In this section, the study group, data collection tool, process of data collection, and analysis of data collection will be presented.

\subsection{Study Group}

15 students from a secondary school that represents a low-level socio-economic society participate in the study. The students are between $13-14$ ages $\left(7^{\text {th }}\right.$ and $8^{\text {th }}$ grade) and 8 of them are girls and 7 of them are boys. The reason why these ages of students are chosen is due to their development level. Children at these ages can follow instructions and can concentrate on things longer. Increasing interest in the subjects such as social awareness, social problems, environmental pollution, social structures, domestic relations, war, disease, etc. are features of these ages' children (Linderman, 1997).

\subsection{Data Collection Tool}

With the aim of representations of gender roles on television, the participants are asked to draw a picture of a man and a woman's gender role as they have seen on television. For this, the researcher said to the students that "Now, I want you to draw a picture of a man's and a woman's gender role. In your picture, there will be a woman and a man doing something which is determined by society. After finishing your picture, I want you to write down your age and sex at the back of the picture". Additionally, the participants are informed that their names will be anonymous, and these pictures will be only used for a study. Later, picture papers are given to the students and they started to draw their pictures.

\subsection{Data Collection Process}

Before starting the study, the researcher contacted the administration of the school and the aim of the study was explained. Later, one volunteer teacher is selected to reach the students. With the volunteer teacher, the researcher started to gather data. First, all students who participated in the study were gathered in a classroom and are told the aim and process of the study. On a set date and time, the researcher and the teacher seated students separately not to affected by each other. After giving instructions, 45 minutes were given to the students to draw their pictures. When they finished their drawings, pictures were collected and thanked the students and the teacher for the participation. Then, the analysis process is started. 


\subsection{Data Analysis}

Pictures of the students are analyzed from the lexical perspective and used content analysis method. Since the aim of the pictures to figure out the gender roles of the woman on television, the aesthetics of the pictures is not to take notice of. First, all pictures are raked through, and tried to find out similarities and differences within the pictures. All pictures are numbered, and the researcher has taken notes behind the pictures trying to find out themes. Some pictures which are out of aim are eliminated. After the researcher's examinations, two other experts also examined the pictures. In the end, three people got together and discussed the meanings of the pictures and decided on the themes emerging from the pictures.

\section{Findings}

In this section, students' pictures are described, and examples of the emergent themes will be presented. In quotations and examples from the pictures and students' opinions, code names were used for students. To protect their identity, at the beginning of the analyses, a code name was given to each student. When we review what students think about the gender role of women in Turkish society according to what they see on TV, six themes emerged. Thus, the findings will be presented according to these themes. These themes are game shows, powerful women, working women, a victim of violence, film series, and alone at home.

Six students draw a woman in a contest show. There are some popular contest shows in prime-time programs on Turkish TV channels. Children draw a picture of one of these contest shows and women in it. Picture 1 and Picture 2 are a cooking contest show.

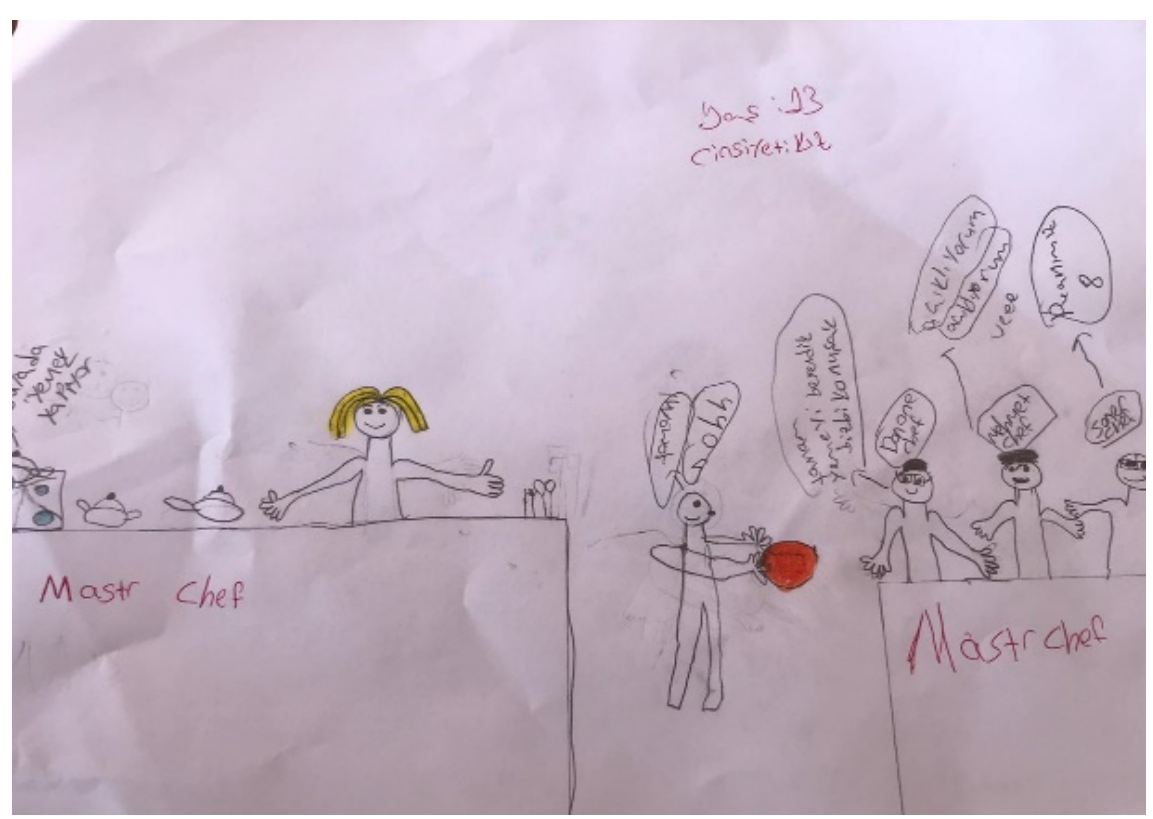

Picture 1 


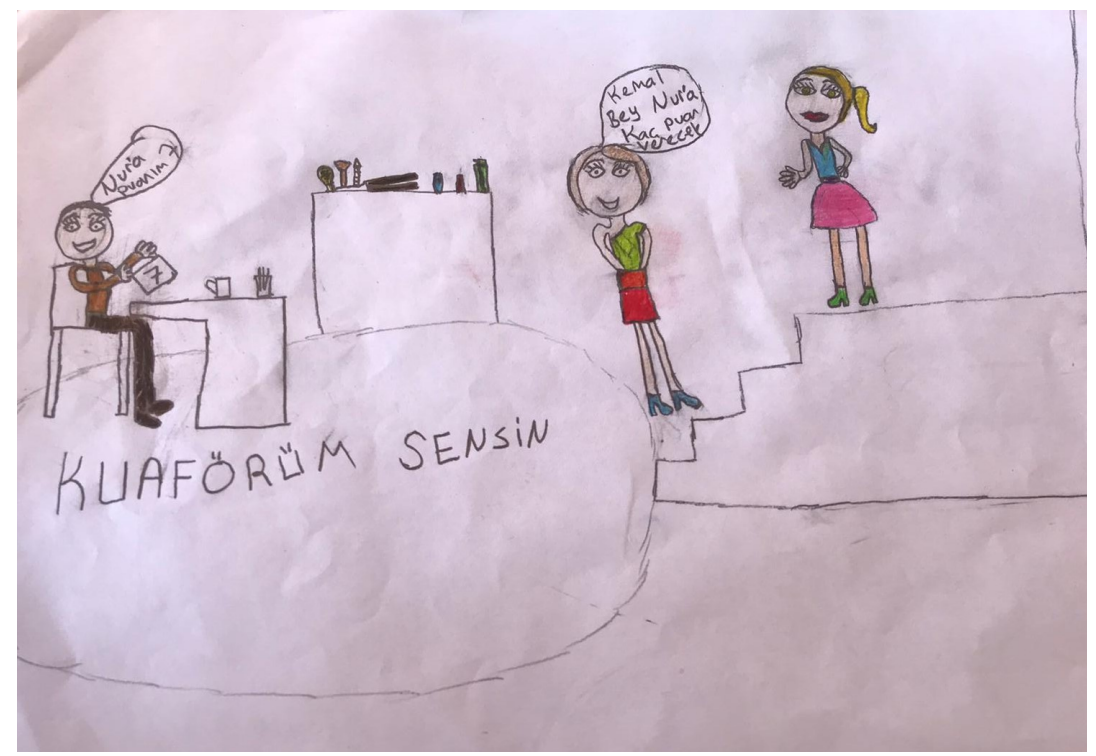

Picture 2

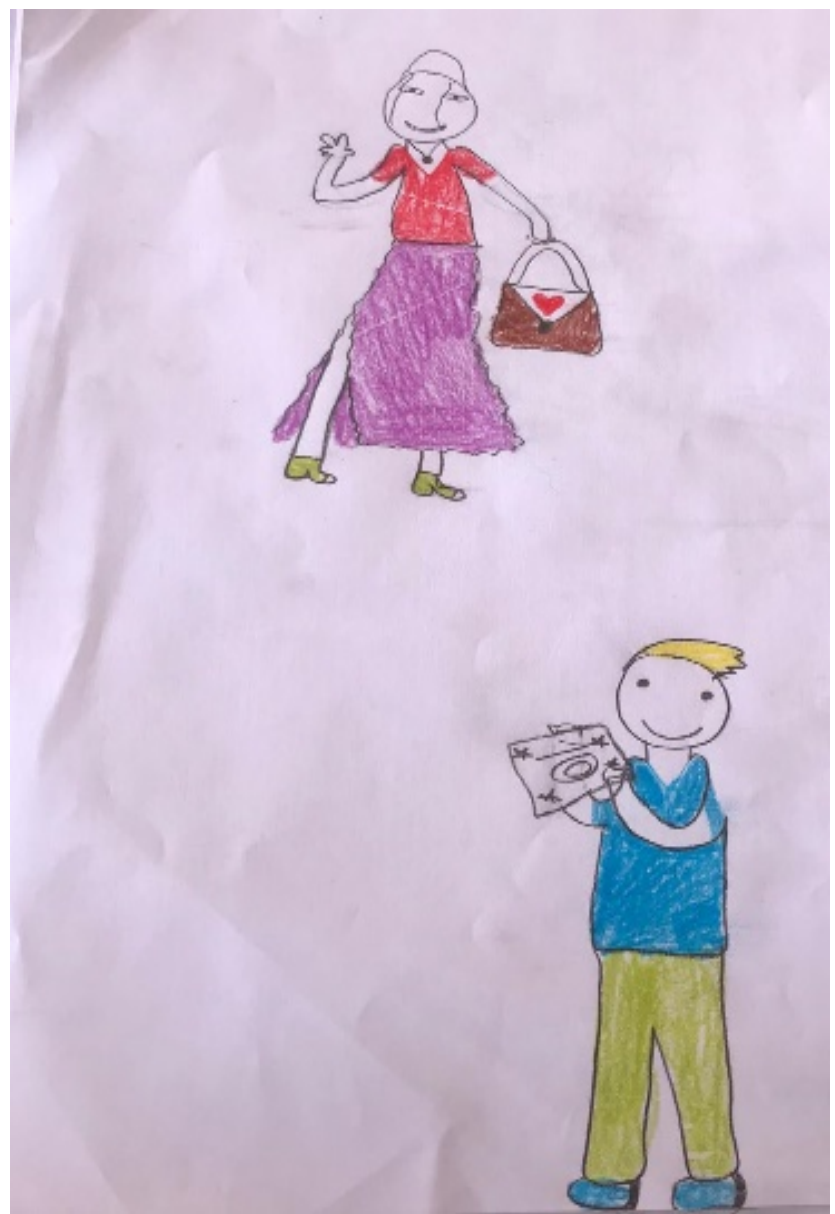

Picture 3

Pictures 3-5 were fashion contest shows. Picture 4 and Picture 5 are a clothing contest show, while Picture $\mathbf{5}$ is a hairstyling contest show. Students drew 
women in these contest shows with makeup and finery. The last contest show is a song contest which is very popular in Turkey (see Picture 6).

Another theme emerged from the pictures is women as a victim of gendered violence. Three students draw pictures of women who are subjected to violence. Picture 7 shows a woman who is trying to protect herself and her children against violence and resisting the violence (see Picture 7).

Another student draws a picture of a woman who is subjected to verbal violence (see Picture 8) while another student draws a picture of a woman who is
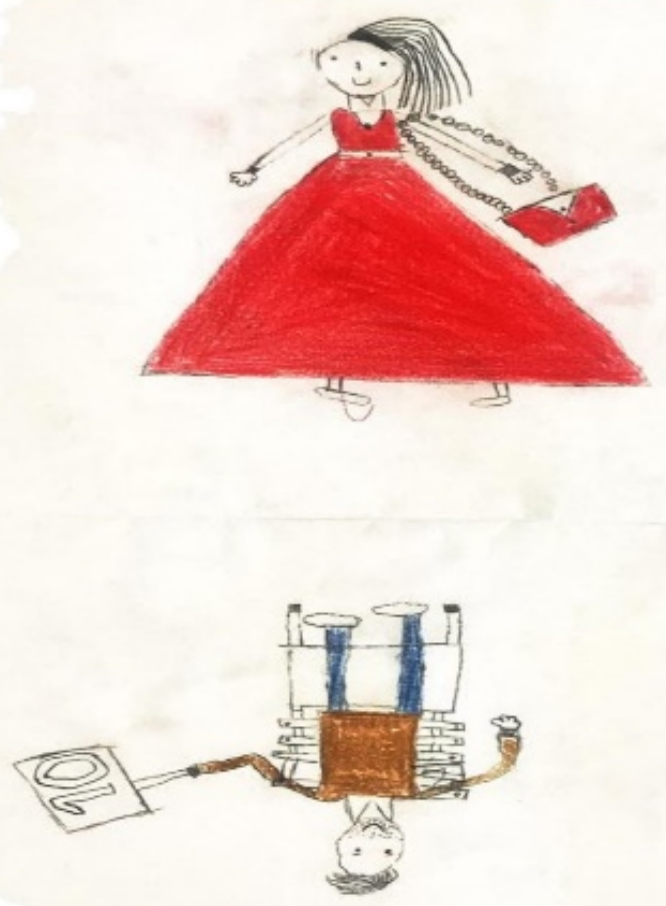

Picture 4
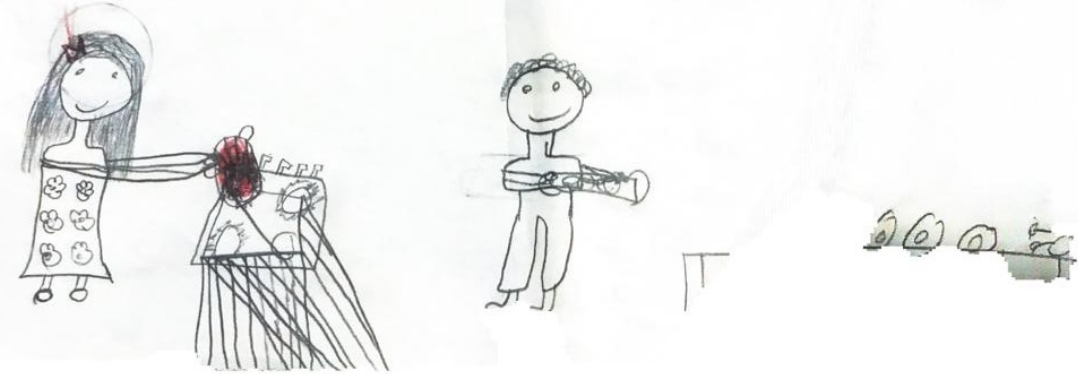

Picture 5 

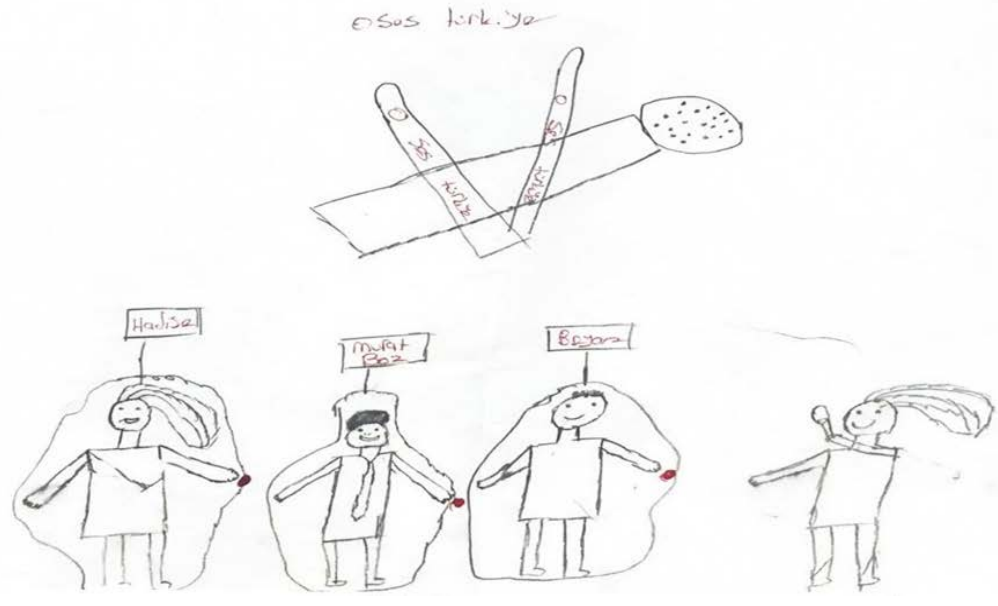

Picture 6

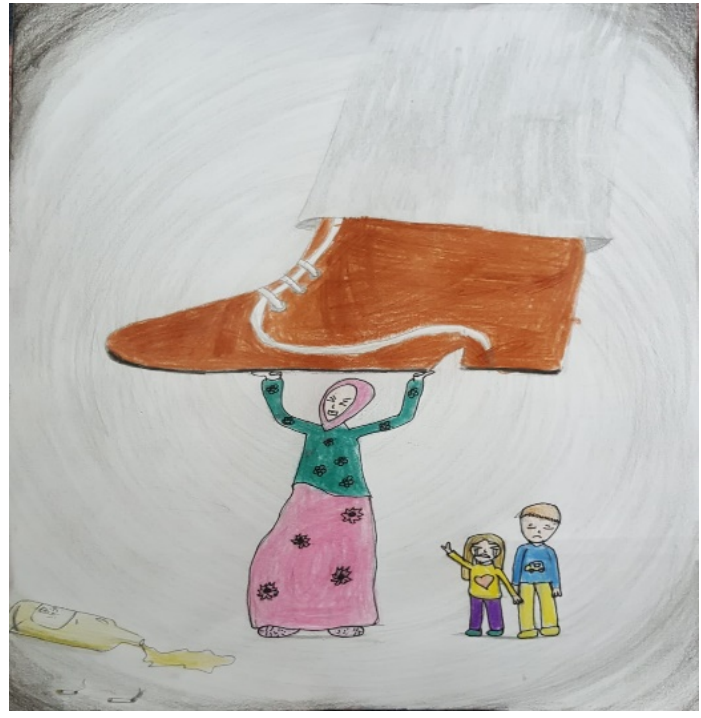

Picture 7

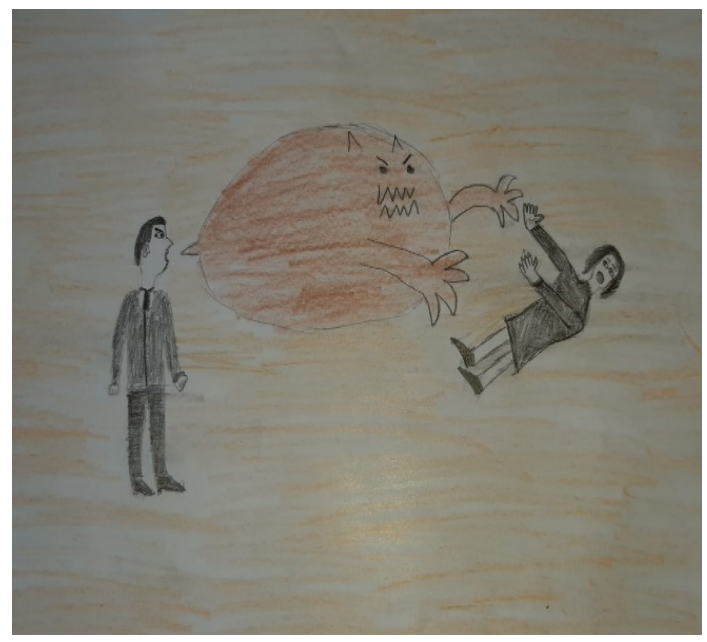

Picture 8 


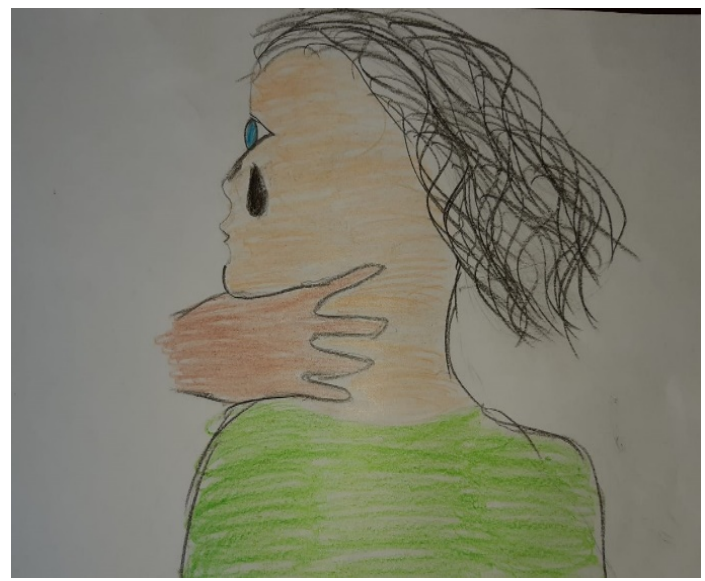

Picture 9

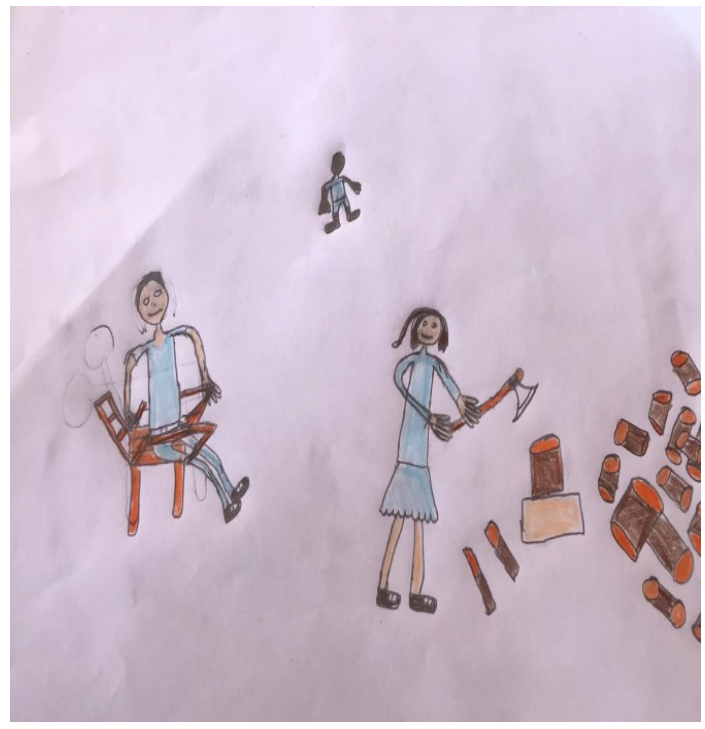

Picture 10

subjected to physical violence (see Picture 9).

A working woman is one of the themes that emerged from the pictures of students. Two students draw pictures of a woman who is working hard. In one of these pictures while a woman is chopping woods a man is just sitting next to her (see Picture 10). In another picture of students, a woman is doing housework like cleaning, taking care of children, and doing laundry in which she is unhappy (see Picture 11).

Two students draw a picture of film series in both series woman is marrying a man. In one of these pictures, a young woman and man are getting married in a film set (see Picture 12). However, in the other picture a young woman is getting married to an old man (see Picture 13). The student said that in the film series young ladies are getting married to an old man just for his money.

One of the students draws a picture of a woman in the living room while a man in the bedroom and both alone (see Picture 14) which means a woman is left alone at home. The last theme that emerged from the drawings is the 


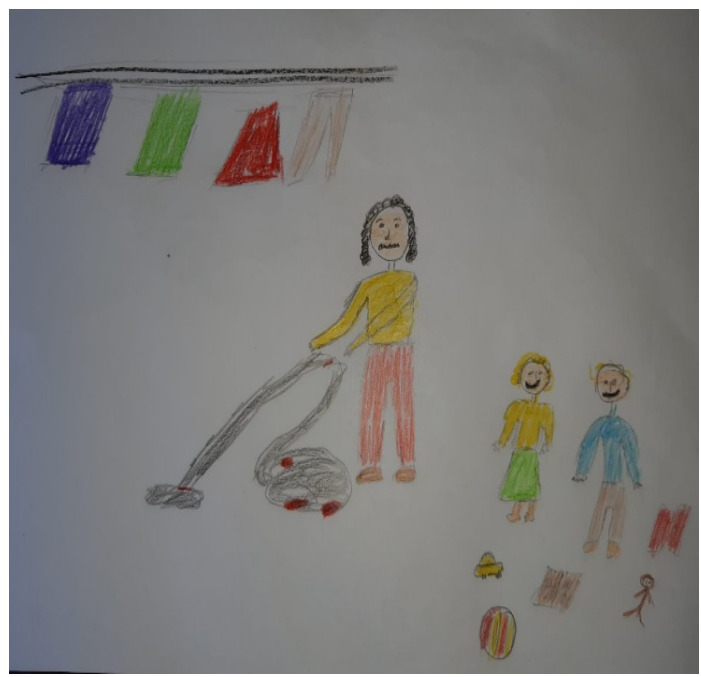

Picture 11

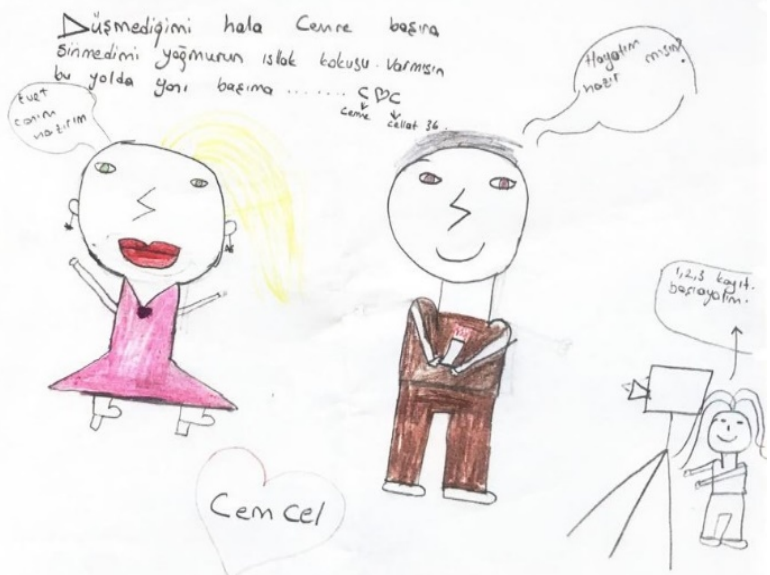

Picture 12

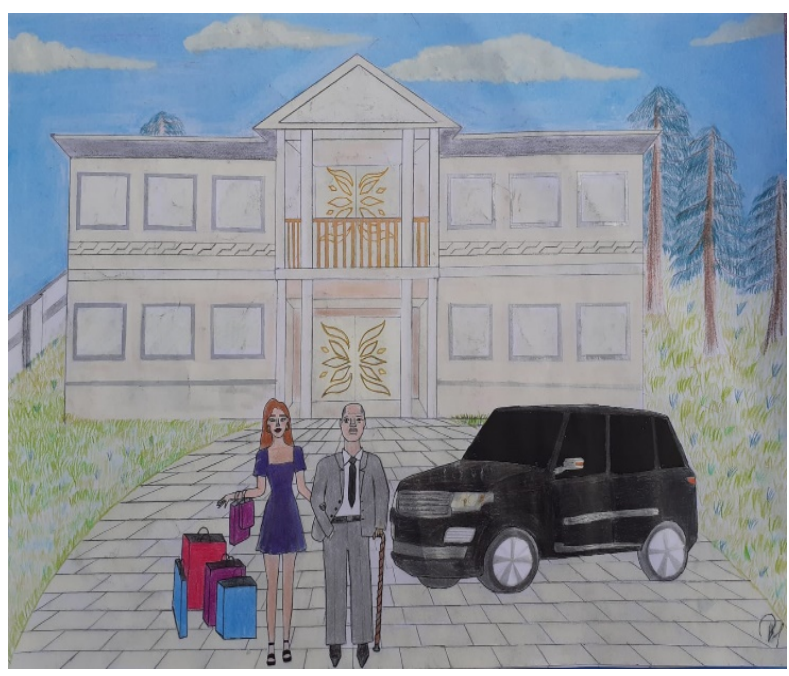

Picture 13 


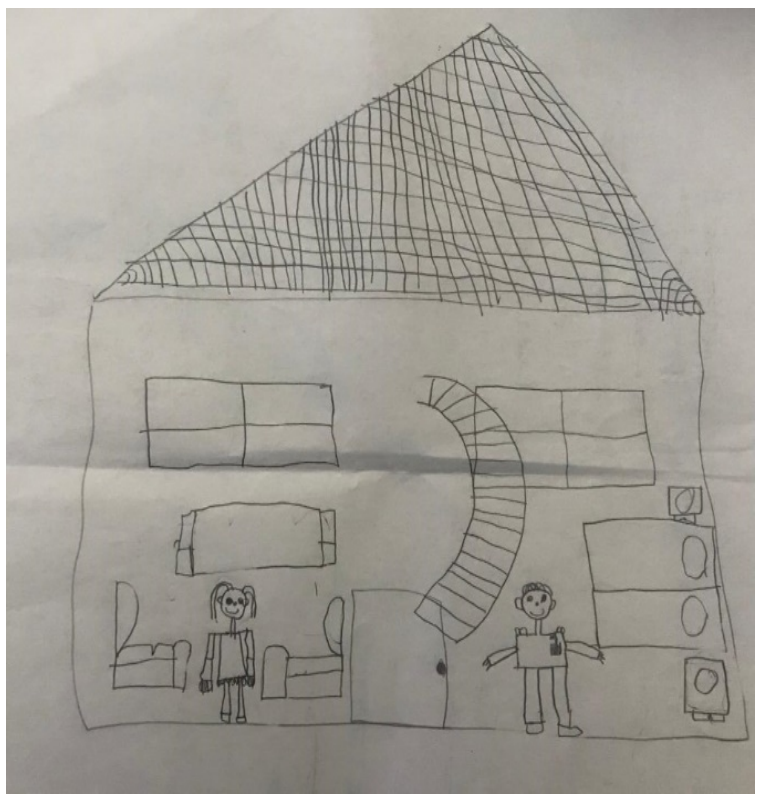

Picture 14

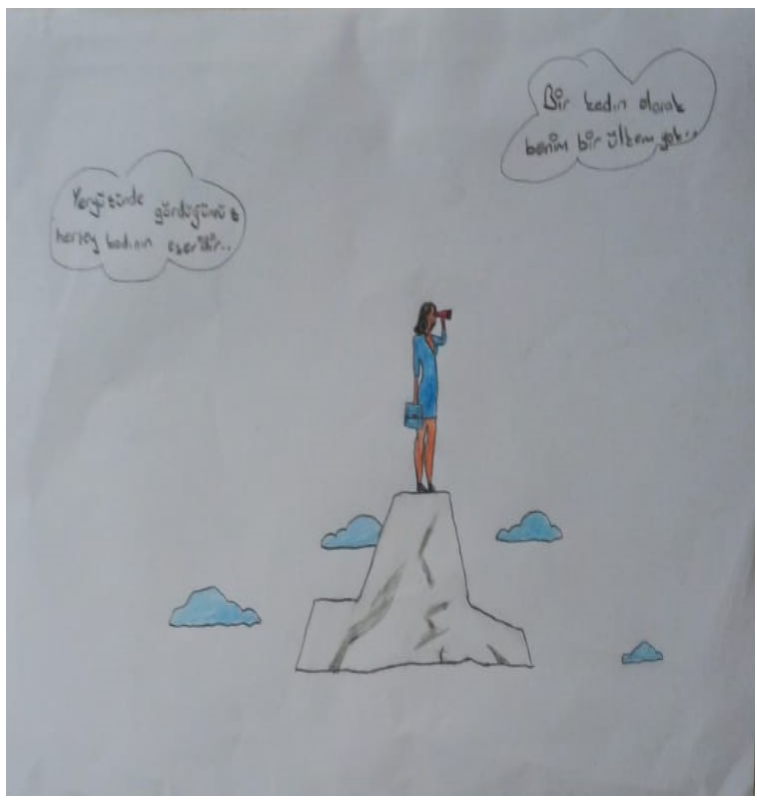

Picture 15

powerful woman. Only one student draws a picture of a powerful woman and told that "everything on the earth is a production of women (see Picture 15).

When we look from a different point of view, six students draw a picture of oppressed women while only one student draws a picture of a powerful woman as seen in the pictures above.

\section{Conclusion}

As perception, attitudes, and thoughts about gender roles may differ from society to society, it can be said that human perceptions of genders are learned expe- 
riences. Nevertheless, it can be also stated that gender roles shaped within the society are a fact of some learned attitudes. This fact can make perception of gender, defining some subjective judgments about gender, having stereotypes, and identifying gender roles possible (Tepe and Gülerarslan Özdengül, 2018). Since gender roles are a learned experience, children learn them from their families, schools, and media. In the technology age, children spent most of their time at media especially on television which is the easiest access one among media tools.

After looking at the drawings of 15 students about the image of a woman they see on television, we should examine what these drawings are tried to tell us. It is a complex process to analyze the pictures. As Yavuzer (2009) stated that "drawing could be regarded as an indicator of mental development and as a way of expressing his or her complex inner world which the child tries to organize on his or her own" (11). This study aims to find out the effect of television on children's perceptions of gender roles. With this aim, students are asked to draw a picture of a woman and her gender roles as they see on television. Having children draw pictures is the most appropriate method to get children's feelings in depth. Children reflect their feelings, thoughts, and manners to drawings (Clarke et al., 2002; Fury, Carlson, \& Sroufe, 1997).

To find out the effect of television on children's perceptions of gender roles, 15 secondary school students in Denizli Turkey draw a picture of women according to what they see on television programs. Six themes emerged from the pictures of students. These are women are at contest shows, film series, alone at home, working woman, powerful woman, and violence against women. One additional theme also can be concluded as oppressed versus powerful women. Studies support the results of this study as stated: "Women image represented by the mass media is like gender roles given by the society. These roles can be defined as a good, fine, and good mother, good wife as well as victim of violence or “sexual object” (Yigitbası \& Sarıcam, 2020). In Buyubaykal's (2012) study, women's taking place on media tools, no matter which program, writing tool, or image, can be gathered into these titles: $1-$ Women as a victim of violence, 2 -Women who are needy and in need of protection, 3-Women as a sexual object, 4-Good wife, 5-Good mother, etc.

Six students draw a picture of women in a contest show. In those pictures, women are finely dressed and have makeups which show us that women are a media object according to the students. Most of the students participated to the study draw the picture of shows when they think about gender roles of women. Sogut (2019)'s study supports the results of this study by stating that "in the internet newspapers, women are mainly represented as "magazine object" and "sexual object" when the women's photographs are taken into consideration and the clothing levels of the displayed women are taken into account" (212).

Three students draw a picture of violence against women. All three pictures refer to a different kind of violence against women; verbal violence, physical vi- 
olence, and oppressed women who are trying to survive themselves and their children. These pictures show us that on television there is violence against women. Students see violence against women mostly on TV series and the news. There are other studies found out that women are represented as holy wife or mother as well as oppressed and leper on mass media tools (Mora, 2005). Mora (2005) expects mass media to be more responsible on publications when we think about the effects of media on people.

Two students draw a picture of working women. However, these women are working at home by doing house-work or other chores while the man is doing nothing. Also, a woman in the picture is taking care of children while doing housework. In society, women's gender role is to take care of children and do housework while men work outside the house as shown on television. Many studies have similar results such as Tepe and Gülerarslan Özdengül (2018). Kalaycı's (2015) study presented that women character are shown at home while doing housework and taking care of children while men character is shown as working outside the home. Lastly, Cinar (2015) examined the course books and found out that in at-home presentation mostly the mother does housework while the father reads the newspaper. In sum, as seen in different studies women are mostly presented while doing housework and taking care of children which means women are matched with indoor works.

Two students draw women within the film series. In both pictures women are getting married which shows that women are attached to men. In most TV films, women are shown as powerless, weak, and needy. Thus, women are supposed to marry a man who will protect them. In one of the pictures, a student draws a picture of a young lady getting married to an old man just for his money. It can be said that this picture shows how miserable a woman is shown on TV programs so that a child is drawing a picture of it. Another theme that emerged from the results is a woman is at home and left alone. The student draws a woman and a man at home but in different rooms alone. Sogut's (2019) study also exhibited that in media women are left alone at home with housework while men are working outside the house. As Veblen (1995) stated that "working outside is not the area of women; women's area is at home to make the house good and lard with herself" (133).

Interestingly, one student draws a picture of a powerful woman. She wrote as "Everything you see in the world is a work of a woman" on the picture. Normally, there is not any study supporting this result. According to Tepe \& Gülerarslan Özdengül (2018), no child mentioned working woman outside the house and related to as a gender role of a woman. However, in this study, one student draws a picture of a powerful and working woman. Of course, some studies state that some images on TV programs about gender roles are changing. Some programs are switching from traditional gender roles toward modern ones.

Looking at from a different point of view, there is another theme that emerged from this study. Women are shown as powerful versus oppressed. Previous stu- 
dies (Sogut, 2019; Tepe \& Gulerarslan Ozdengul, 2018; Kalayc1, 2015) presented that women's image on media is shown as oppressed which can be also concluded from this study. Six students draw a picture of oppressed women. On the other hand, a new result emerged from this study that there is a picture of powerful women which shows that the gender roles are changing on TV programs. Even though none of the previous studies presented powerful women this study does.

As with all studies, this study has some limitations. Firstly, this study could be done with more students to obtain more detailed data. Thus, future studies researchers could do this study with more students from different schools to get diverse data. Secondly, as a data collection tool, only documents are used. Besides pictures, interviews could be done to understand what students see on TV programs. Future studies can use both document analysis and interviews as data collection methods.

\section{Conflicts of Interest}

The author declares no conflicts of interest regarding the publication of this paper.

\section{References}

Binark, M., \& Gencel Bek, M. (2010). Critical Media Literacy. Kalkedon Publishing.

Butler, J. (1990). Gender Trouble: Feminism and the Subversion of Identity. Routledge Publishing.

Buyubaykal, I. C. (2012). The Phenomenon of Women in the Media. Istanbul University Communication Faculty Journal, Online Version (28).

Cinar, P. (2015). Female Characters in Clothing in Illustrated Children's Books. Ankara University Educational Sciences Faculty Journal, 1, 1-18.

Clarke, L., Ungerer, J., Chahoud, K., Johnson, S., \& Steifel, I. (2002). Attention Deficit Disorder Is Associated with Attachment Insecurity. Clinical Child Psychology and Psychiatry, 7, 179-198. https://doi.org/10.1177/1359104502007002006

Connell, R. W. (1998). Social Gender and Power. Ayrıntı Publishing.

Dokmen, Y. Z. (2010). Gender: Social and Psychological Explanations (2 ${ }^{\text {nd }}$ ed.). Remzi Publishing.

Eroglu, E. (2015). Social Norms from Past to Present. Akademic Looking Journal, 50, 299-308.

Fury, G., Carlson, E. A., \& Sroufe, L. A. (1997). Children's Representations of Attachment Relationships in Family Drawings. Child Development, 68, 1154-1164. https://doi.org/10.2307/1132298

Giddens, A. (2000). Sociology (Translated by H. Ozel and G. Cemal). Ayraç Publishing.

Gregory, M. E. (2013). Children's Media Usage: Positive Psychological Approach. In Turkish Children and Media Congress Book (pp. 91-115). Child Charity.

Kalayc1, N. (2015). An Analysis of Cartoons in Terms of Gender Equality: Pepee. Education and Science, 40, 243-270. https://doi.org/10.15390/EB.2015.3836

Kılıc1, S. (2009). Looking at the Concept of Gender in Animated Films: Examples of Ice Age, Shrek, and Winx Club: The Secret of the Lost Kingdom. Unpublished Master 
Thesis. Kocaeli University Social Sciences Institute.

Linderman, M. G. (1997). Art in the Elementary School. Mc Graw Hill.

Mora, N. (2005). Sexism Reproduced in Mass Media and Its Reflection on Society. International Journal of Human Sciences, 1, 1-7.

O'Bryant, S., \& Corder-Bolz, C. R. (1978). The Effects of Television on Children's Stereotyping of Women's Work Roles. Journal of Vocational Behavior, 12, 233-244. https://doi.org/10.1016/0001-8791(78)90038-6

Sabuncuoglu, A. (2006). Gender in Television Commercials. Unpublished Master Thesis. Ege University Social Sciences Institute.

Saygın Sarbay, Z. (2015). The Promotional Love of Çelik and Çeliknaz Gender Roles in Arçelik Commercial Films. Ankara University ILEF Journal, 1, 95-114. https://doi.org/10.24955/ilef.305272

Sogut, F. (2019). New Media and Representation: Presentation of Gender Identity in Internet Journalism. Akdeniz University Communication Faculty Journal, 31, 212-231. https://doi.org/10.31123/akil.531977

Tepe, M., \& Gülerarslan Özdengül, A. (2018). Interpretation of Female Figures in the Adverts from Children's Perspective within the Frame of Social Gender Percepts: A Case of Amasya Province. TRT Academy, 3, 563-579.

Uluyagc1, C., \& Yılmaz, A. (2007). Presentation of Social Gender Roles Concerning Children in Television Commercials. Galatasaray University Communication Faculty Journal, 6, 141-157.

Veblen, T. (1995). Leisure Class (Translated by İnci User). Marmara University.

Yavuzer, H. (2009). Child with Drawings (3rd ed.). Remzi Publishing.

Yigitbası, K. G., \& Sarıcam, S. (2020). Representation of Gender Roles and Media: The Case of TRT Children's Magazine. Türkiye Communication Research Journali, Online First, 19-45. 